\title{
Chemical Composition of a Mud Volcano LUSI and the Health Risk Involved based on the Air Quality Index that Occurred as a Result of Disastrous Gas Exploration Drilling Activities in Sidoarjo, Indonesia
}

(Komposisi Kimia daripada Gunung berapi LUSI dan Risiko Kesihatan yang Terlibat Berdasarkan Indeks Kualiti Udara Hasil daripada Aktiviti Penggerudian Eksplorasi Gas Bencana di Sidoarjo, Indonesia)

\author{
DEWI HidAYATI, ISMAIL B.S., SHUHAIMI-OTHMAN M. \& NORElA SUlaimaN*
}

\section{ABSTRACT}

LUSI (Lumpur "mud"-Sidoarjo) is the mud volcanic which was initiated by the failed gas drilling exploration activities carried out near an urban area. The evaluation of the LUSI mud volcanic emission and its dried mud effects on air pollution and human health was carried out from 2011 to 2012. The concentrations of particulate matter (PM $\left.{ }_{2 \cdot 5}\right)$, hazardous gases $\left(\mathrm{H}_{2} \mathrm{~S}, \mathrm{SO}_{2}, \mathrm{NO} \mathrm{O}_{2}\right)$, volatile organic compounds (VOC): Including total hydrocarbons (THC)), toluene $\left(\mathrm{C}_{6} \mathrm{H}_{5} \mathrm{CH}_{3}\right)$ and benzene $\left(\mathrm{C}_{6} \mathrm{H}_{6}\right)$ as well as heavy metals ( $\mathrm{Pb}, \mathrm{Cr}$ and $\mathrm{Cd}$ ) were measured following standard methods. The results showed that the average concentration of $P M_{2.5}$ ranged from $24.0-399.9 \mu \mathrm{g} / \mathrm{m}^{3}, \mathrm{H}_{2} \mathrm{~S}: 1.53-2.92 \mathrm{ppm} ; \mathrm{SO}_{2}: 0.021-1.321 \mathrm{ppm}$ and $\mathrm{NO}_{2}:$ 0.007-0.076 ppm. The VOC included total hydrocarbons from 0.57-0.96 ppm, toluene 0.33-0.92 ppm and benzene 0.33-0.40 ppm. Furthermore, heavy metal concentrations were as follows: $\mathrm{Pb} 2.6-37.34 \mu \mathrm{g} / \mathrm{m}^{3} ; \mathrm{Cr} 0.14-12.8 \mu \mathrm{g} / \mathrm{m}^{3}$ and Cd 0.78-4.16 $\mu \mathrm{g} / \mathrm{m}^{3}$. LUSI contributed to increased air pollution primarily through $\mathrm{H}_{2} \mathrm{~S}, \mathrm{SO}_{2}$ and $P M_{2.5}$. The Air Quality Index (AQI) of $P_{25}$ (164-217) and $\mathrm{SO}_{2}$ (235-291) showed that the air quality at the disaster area was 'very unhealthy'. Backward trajectories indicated that the wind direction may have had an impact on the air pollution load.

Keywords: Air quality index; heavy metals; VOC; volcano

\section{ABSTRAK}

LUSI (Lumpur "lumpur" -Sidoarjo) adalah bencana lumpur gunung berapi yang disebabkan oleh kegagalan aktiviti penggerudian gas yang terjadi berhampiran dengan kawasan bandar. Penilaian kesan pelepasan gas gunung berapi LUSI dan lumpur keringnya terhadap pencemaran udara dan kesihatan manusia ini telah dijalankan pada tahun 2011 hingga 2012. Kepekatan zarahan halus ( $\left.\mathrm{PM}_{2.5}\right)$, gas berbahaya $\left(\mathrm{H}_{2} \mathrm{~S}, \mathrm{SO}_{2}, \mathrm{NO}_{2}\right.$, VOC: jumlah hidrokarbon (THC)), toluena $\left(\mathrm{C}_{6} \mathrm{H}_{5} \mathrm{CH}_{3}\right)$ dan benzena $\left(\mathrm{C}_{6} \mathrm{H}_{6}\right)$ serta logam berat $(\mathrm{Pb}, \mathrm{Cr}$ and $\mathrm{Cd})$ diukur menggunakan metod piawaian. Keputusan menunjukkan purata kepekatan bagi $P M_{2.5}$ antara 24.0-399.9 $\mu \mathrm{g} / \mathrm{m}^{3}, \mathrm{H}_{2} \mathrm{~S}:$ : 1.53-2.92 ppm; $\mathrm{SO}_{2:}$ 0.021-1.321 ppm dan $N O$. 0.007-0.076 ppm. VOC termasuk jumlah hidrokarbon daripada 0.57-0.96 ppm, toluena 0.33-0.92 ppm dan benzena 0.33-0.40 ppm. Tambahan pula, kepekatan logam berat adalah seperti berikut: $\mathrm{Pb}$ 2.6-37.34 $\mu \mathrm{g} / \mathrm{m}^{3} ; \mathrm{Cr} 0.14-12.8 \mu \mathrm{g} / \mathrm{m}^{3}$ dan $\mathrm{Cd}$ 0.78-4.16 $\mu \mathrm{g} / \mathrm{m}^{3}$. LUSI menyumbang kepada peningkatan pencemaran udara terutamanya $\mathrm{H}_{2} \mathrm{~S}, \mathrm{SO}_{2}$ dan $\mathrm{PM}_{25}$. Merujuk kepada Indeks Kualiti Udara (AQI) PM ${ }_{2.5}$ (164-217) dan $\mathrm{SO}_{2}$ (235-291) menggambarkan bahawa kualiti udara di kawasan bencana tersebut adalah 'sangat tidak sihat'. Trajektori udara kebelakang menunjukkan arah angin mungkin mempunyai kesan ke atas beban pencemaran udara.

Kata kunci: Gunung berapi; indeks kualiti udara; logam berat; VOC

\section{INTRODUCTION}

The LUSI (Lumpur 'mud'-Sidoarjo), mud volcano has been emitting hot mud in the Sidoarjo district of East Java, Indonesia since May 29, 2006 as a result of extreme pressure of the subsurface mud layers, the cause of which could be linked to the gas exploration activities that were carried out in that area. The LUSI mud volcanic eruption has been predicted to continue for the next 26 years (Davies et al. 2011). An evaluation of the hazardous gases emitted is important as huge volumes of the hot mud, which can amount to almost $160,000 \mathrm{~m}^{3} /$ day, in the form of a mixture of mud, boiling water and volcanic gases (Brown 1990; Milkov 2005; Plumlee et al. 2008; UNDAC 2006) are being emitted. Gas from the offshore mud volcanoes are released directly into the atmosphere and thus directly affect the content of the atmospheric gases (Akesson 2008). The smell of rotten eggs has been detected in the vicinity of the LUSI mud volcano crater, indicating the presence of hydrogen sulfide $\left(\mathrm{H}_{2} \mathrm{~S}\right.$ ) (ATSDR 2006; Mazzini et al. 2007; Plumlee et al. 2008; Sher 1998). In addition, due to the disastrous gas drilling activities, natural gases have also been reported to have been emitted at random sites surrounding the mud volcano, hence potentially increasing the content 
of volatile organic compounds. The LUSI mud volcanic emission has been occurring in the semi urban and densely populated district of Sidoarjo, plus it is also close to the densely populated urban and industrial areas, namely Surabaya (ADB 2006; Kono 2003;). Several previous studies have reported that (54-90\%) of LUSI contained heavy metals such as aluminium, iron, zinc, chromium, lead and copper. Since $90 \%$ of the particle size was less than $10 \mu \mathrm{m}$, approximately $45 \%$ of dried LUSI mud could be respired into the alveoli of the lungs (Hidayati et al. 2017, 2014, 2013; Plumlee et al. 2008). Accordingly, LUSI could have contributed to the ambient air pollution, which in the present study is highlighted for several parameters in the urban areas. The aim of the study was to measure and evaluate the effects of the chemical constituents of the LUSI mud volcanic emission and the particulate matter from the dried mud on air pollution and human health risk in the affected area. There were several relevant parameters which included fine particulate matter $\left(\mathrm{PM}_{2.5}\right), \mathrm{NO}_{2}, \mathrm{SO}_{2}, \mathrm{H}_{2} \mathrm{~S}$, heavy metals and volatile organic compounds (VOCs). Monitoring of the air pollution status at the mud volcano area and the human health risk factors involved is important in order to minimize any serious consequences.

\section{METHODS}

\section{DESCRIPTION OF SAMPLING STATIONS AND SURVEY TIMES}

With reference to Figure 1, the large mud pond is surrounded by an embankment which was built to prevent the LUSI mud from flooding and subsequently flowing into the nearby human settlements and roads. The air sampling sites were selected based on their ease of access as well as for being representative of the breathing zone of individuals living in the adjacent settlements. Three sampling stations were selected namely A1 (7³1' 59.8' $\left.\mathrm{S} ; 112^{\circ} 43^{\prime} 18.1^{\prime \prime} \mathrm{E}\right)$, located at approximately $0.5 \mathrm{~km}$ from the LUSI mud

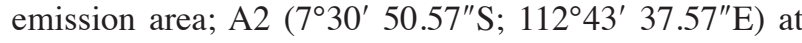
approximately $1 \mathrm{~km}$ from the LUSI mud emission area and close to the human settlement and A3 ( $7^{\circ} 32^{\prime} 36.57^{\prime \prime} \mathrm{S}$; $\left.112^{\circ} 44^{\prime} 35.06^{\prime \prime} \mathrm{E}\right)$, approximately $4 \mathrm{~km}$ from the LUSI mud emission area and close to the motorized traffic and roads. Air samples were taken on five designated days of the survey conducted from January 2011 to April 2012 (based on previous seasonal studies).

\section{AIR SAMPLING AND METHODOLOGY OF ANALYSES}

The portable wet-chemical system using the RAC 5-Gas sampler (LLC 3293 Ash Burton Chase NE Rosewell GA 30075) and a high volume air sampler (HVS -Tisch Environment, TE-6070V-2.5) were used to collect the particulate matter and polluted air samples of the ambient air. The levels of volatile organic compounds (VOCs) and $\mathrm{H}_{2} \mathrm{~S}$ were measured on-site using the photo-ionization detector (PID-2020 ppb PRO Photovac). Quantification of heavy metals was done using the Graphite Furnace Atomic Absorption Spectrophotometer (GFAAS-Hitachi Z-2000 Series), whilst for $\mathrm{SO}_{2}$ and $\mathrm{NO}_{2}$ analyses, the UV 1100 Spectrophotometer was used.

Briefly, the gas samples (for air quality measurement) which included sulfur dioxide $\left(\mathrm{SO}_{2}\right)$, nitrogen dioxide $\left(\mathrm{NO}_{2}\right)$ and the heavy metals (lead, cadmium and chromium), were collected simultaneously in the liquid state using the RAC 5-gas sampler (absorption by the reagent solutions). As a portable electric generator was used, the vacuum pump of the RAC gas sampler was operated at a flow rate of $0.175 \mathrm{~L} / \mathrm{min}$, whereby the air

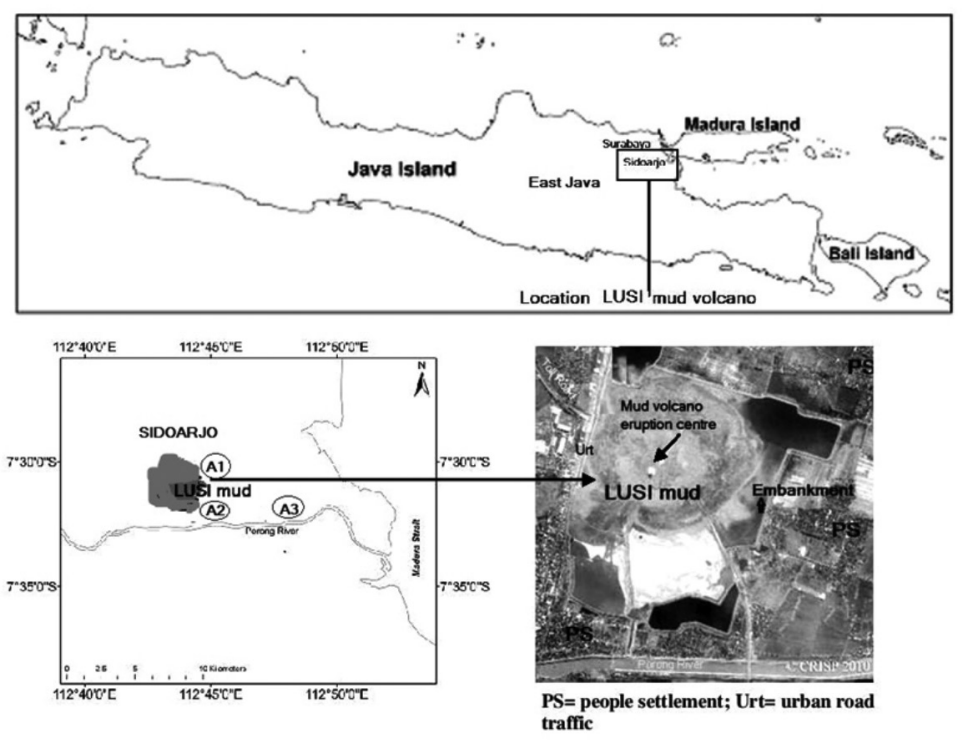

FIGURE 1. The air sampling sites. The LUSI mud volcano is located in the Sidoarjo district, East Java and the mud is collected in a pond that is surrounded by an embankment. Sampling sites at the surrounding embankment areas were labelled A1, A2 and A3 (circles) 
was drawn in through a conical rain shield and inlet tube. The particulate matter was separated by a membrane-type inlet filter, whereby the air entered the inlet manifold and was streamed into five equal volumes that flowed through tubing to the bubblers that contained $50 \mathrm{~mL}$ of the reagent. After $60 \mathrm{~min}$, the collected air samples in the reagent tubes were transferred to pre-washed polyethylene bottles which were covered with solid, leak-proof threaded caps, prior to laboratory analyses for $\mathrm{NO}_{2}$ and $\mathrm{SO}_{2}$ using the UV 1100 Spectrophotometer (by the Phenol disuphonic acid method and the pararosanilin method, respectively) (Gokhale 2009; SNI 2005a; SNI 2005b). Meanwhile, the samples in the acidic reagents for determination of metal content (Queensland EPA 1997) were analyzed using the GFAAS which was operated in accordance to the USEPA method 200.9 (Creed et al. 1994).

The fine particulate matter, $\mathrm{PM}_{2.5}$, was collected using the HVS that was operated in accordance to the USEPA methodology for particulate air monitoring (RFPS-0202141). The weighed filter paper (Whatman quartz micro fiber $20.3 \times 25.4 \mathrm{~cm}$ ) was placed in the filter holder made of stainless steel (size 8 " $\times 10 ")$. When the HVS was switched on, the fine particulate matter from the ambient air flowed into the coffers of the HVS and got trapped in the filter paper. After $60 \mathrm{~min}$, the filter paper was carefully removed from the filter holder and placed in a labelled plastic container. Then, the filter paper was immediately taken to the laboratory for analysis using the gravimetric method. Initially, the filter paper was dried in an oven at $40^{\circ} \mathrm{C}$ for $3 \mathrm{~h}$, then cooled in a pre-weighed flask that was weighed several times to determine the final weight. The concentration of the fine particles in the air was determined based on the difference in weight before and after the samples of fine particulate matter were weighed and expressed in micrograms per cubic meter $\left(\mu \mathrm{g} / \mathrm{m}^{3}\right)$. The vOCs including total hydrocarbon, benzene, toluene and $\mathrm{H}_{2} \mathrm{~S}$ were analyzed in-situ using a PID.

\section{TRAJECTORY WIND DIRECTION ASSUMPTION}

The assumed wind direction using trajectory analysis was obtained using the HYSPLIT (hybrid single- particle lagrangian integrated trajectory) model and estimation was done within $24 \mathrm{~h}$, from a height of $500 \mathrm{~m}$ (Draxler \& Rolph 2013; Rolph 2013).

\section{HEALTH RISK BASED ON AIR QUALITY INDEX (AQI)}

Estimation of air quality on human health was measured based on the AQI (Air Quality Index) which was obtained using the USEPA equation, 'AirNow' (http://www.airnow. gov/index.cfm?action=resources.conc_aqi_calc) and referred to as the AQI value in the following equation:

$$
A Q I=\frac{\left(A Q I_{H i}\right)-\left(A Q I_{L o}\right)}{\left(\operatorname{Con}_{H i}\right)-\left(\operatorname{Con} C_{L o}\right)} x\left(\left(\operatorname{Con} C_{i}\right)-\left(\operatorname{Con} C_{L o}\right)\right)+\left(A Q I_{L o}\right)
$$

where $\operatorname{ConC}_{i}$ is the input concentration of a given pollutant; $\operatorname{ConC}_{L o}$ is the concentration breakpoint that is less than or equal to $\operatorname{ConC}_{i}$; $\operatorname{ConC}_{H i}$; is the concentration breakpoint that is greater than or equal to $\operatorname{ConC}_{i} ; A Q I_{L o}$ is the AQI value corresponding to $\operatorname{ConC}_{i}$; and $A Q I_{H i}$ is the $\mathrm{AQI}$ value corresponding to $\operatorname{ConC}_{i}$.

The health status in accordance to the USEPA standards (2006) was divided into six categories namely good, moderate, unhealthy for sensitive groups, unhealthy, very unhealthy and dangerous.

\section{RESULTS}

\section{CURRENT CONDITIONS OF SAMPLING STATIONS}

The meteorological conditions, one of the air quality factors (Hawkins \& Holland 2010; Tai et al. 2010; Tiwari et al. 2012) was obtained from the local weather forecast (http://www.wunderground.com/weather-forecast/ID/ Juanda.html) and summarized in Table 1.

The mean temperature reading during the time of sampling was $28^{\circ} \mathrm{C}$. Hasan (2003) reported that the rainy season in the areas along the Brantas River, including Sidoarjo, occurred from November to April, while the dry season was from May to October. Similarly, rainy days in the current study areas were observed in January and February (5 times/week) and in March and April (2-4 times/week) whereas, the dry season occurred in October. In general, the rain usually occurred in the evening hence, there was no difficulty in obtaining the air samples during the rainy season. The plumes of steam and gas emitted from the LUSI mud volcano are presented in a series of satellite images from CRISP $(2012,2011,2010)$, (Figure 2) indicating the active state of the mud volcano.

The backward trajectories within $24 \mathrm{~h}$ from a height of $500 \mathrm{~m}$ indicated that the wind direction in January 2011 and February 2011 was from the northwest. However, the wind direction in October 2011, March 2012 and April 2012 was from the southeast, west and east, respectively. The wind directions may have an impact on the air pollution load (Lodhi et al. 2009).

A summary of ambient air quality at the mud volcano area (Table 1), showed that the average maximum concentration for several parameters during January 2011 - April 2012 including $\mathrm{PM}_{2.5}$ ((A1=299.63; A2=190.45; $\left.\mathrm{A} 3=399.9) \mu \mathrm{g} / \mathrm{m}^{3}\right), \mathrm{H}_{2} \mathrm{~S}((\mathrm{~A} 1=2.92 ; \mathrm{A} 2=2.53 ; \mathrm{A} 3=2.30)$ ppm); $\mathrm{SO}_{2}((\mathrm{~A} 1=1.096 ; \mathrm{A} 2=0.938 ; \mathrm{A} 3=1.340) \mathrm{ppm})$ and total $\mathrm{HC}((\mathrm{A} 1=0.89 ; \mathrm{A} 2=0.96 ; \mathrm{A} 3=0.92) \mathrm{ppm})$ were at levels above all the stipulated permissable standards. Meanwhile, the concentration of $\mathrm{Pb}((\mathrm{A} 1=37.34 ; \mathrm{A} 2=29.52 ; \mathrm{A} 3=22.83)$ $\mu \mathrm{g} / \mathrm{m}^{3}$ ) exceeded the standard permissable levels of NAAQS USEPA (1990). However, the ambient air quality and Permissible Exposure Limits (PELs) were at a safe level in the East Java Province (2009) according to the standards of the Occupational Safety and Health Administration (OSHA).

Several investigations have shown that the $\mathrm{PM}_{2.5}$ concentration is negatively correlated with wind speed 


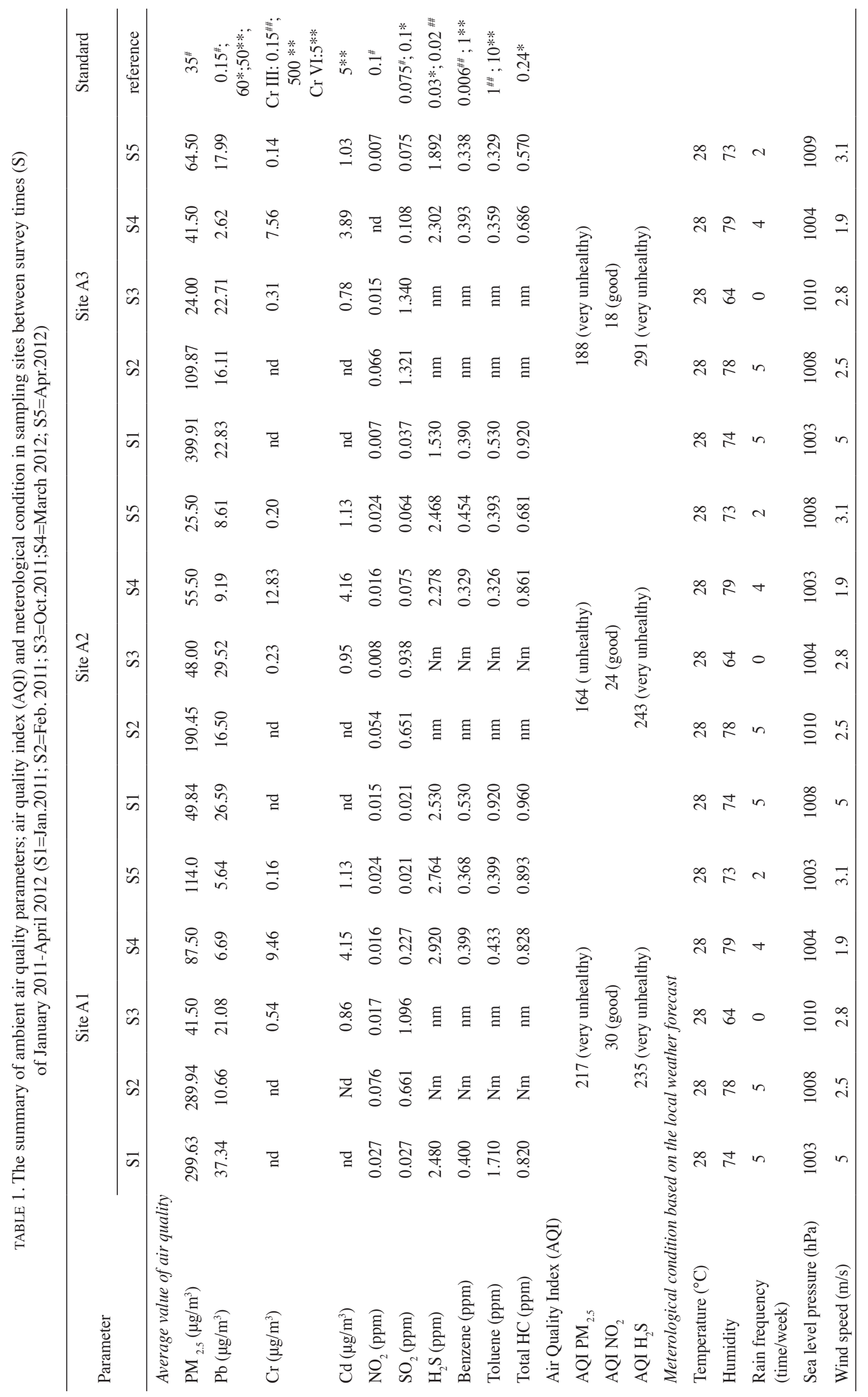




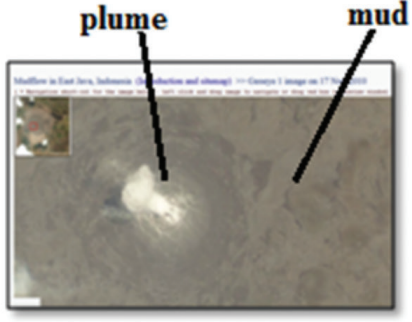

2010

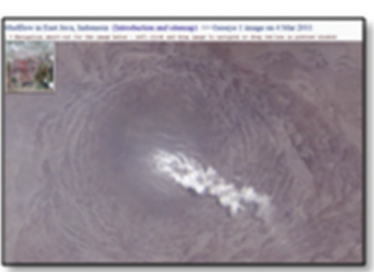

2011

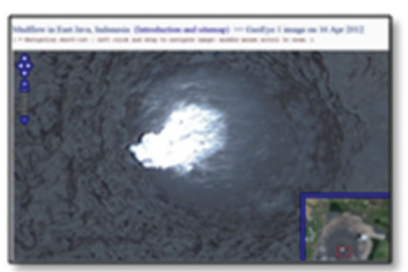

2012

FIGURE 2. Satellite images of the LUSI mud volcano for the year of 2010, 2011 and 2012

(CRISP 2012, 2011, 2010)

(Hawkins \& Holland 2010; Tai et al. 2010; Yadav et. al. 2014). However, Hosiokangas et al. (2004) found that high wind speed may increase $\mathrm{PM}_{25}$ concentration due to the process of wind-blown resuspended dust. In line with Hosiokangas's findings (2004), there was high concentration of $\mathrm{PM}_{2.5}$ in the current study (Table 1 \& Figure 3) and these readings were higher in January 2011 $\left(299.63 \pm 50.70 \mu \mathrm{g} / \mathrm{m}^{3}\right)$ and February $2011(289.94 \pm 49.21$ $\mu \mathrm{g} / \mathrm{m}^{3}$ ) when the wind speed was high (Table 1). Also, for the sampling period in October $2011(42.50 \pm 7.78 \mu \mathrm{g} /$ $\left.\mathrm{m}^{3}\right)$, March $2012\left(87.50 . \pm 14.85 \mu \mathrm{g} / \mathrm{m}^{3}\right)$ and April 2012 $\left(114 . \pm 19.35 \mu \mathrm{g} / \mathrm{m}^{3}\right)$ the lower wind speed was followed with lower concentration of $\mathrm{PM}_{2.5}$.

As mentioned earlier, the high $\mathrm{PM}_{2.5}$ was brought about by the wind-blown resuspended dust, believed to have originated from the aggregation of several sources: from the dry mud of LUSI which constituted about $45 \%$ fine particulates that can produce dust size particles of $<2.5 \mathrm{~m}$ which can be accidentally inhaled into the respiratory system and can also be swallowed from hand to mouth (Plumlee et al. 2008); from the construction of the embankment (UNDAC 2006) and access roads; from dust of the unpaved roads; and from fumes emitted by motor vehicles. The backward trajectory (Figure 3), of the wind direction in January and February 2011 caused an increase in the risk of transported dust blown from the LUSI mud volcano area to the sampling sites. Moreover, the spatial trend of the increase in $\mathrm{PM}_{2.5}$ indicated that the stations closer to the dust point sources, namely, A1 (close to the LUSI mud volcano and embankment construction work) and A3 (close to dust emission from the access road construction, unpaved roads and motor vehicles) had significantly higher $\mathrm{PM}_{2.5}(p<0.05)$ than that at the sampling stations of A2.

Table 1 shows that the metal concentration was in the order of $\mathrm{Pb}>\mathrm{Cr}>\mathrm{Cd}$. All observed $\mathrm{Pb}$ concentrations were lower than the permissible level as stipulated by OSHA $\left(50 \mu \mathrm{g} / \mathrm{m}^{3}\right)$. Low $\mathrm{Pb}$ concentration was found in the environment and in the water of the mud volcanoes (Uruioc 2011). Contribution of the mud eruption to $\mathrm{Pb}$ pollution in the ambient air was relatively low (ATSDR 2007a). Most of the $\mathrm{Pb}$ generated was from human activities which included metal processing, chemical industries and emission from vehicles. Previously, UNDAC (2006) reported that $\mathrm{Pb}$ pollution in the ambient air of the LUSI mud volcano area was primarily caused by motorized vehicles (traffic) plus mud digging and pumping activities. The presence of $\mathrm{Pb}$ was also believed to have arisen from industrialized activities such as shipbuilding, metal processing and petroleum (ADB 2006; Kono 2003) as well as from the urban traffic along the Surabaya and Sidoarjo city roads. However, despite the Indonesian government's efforts at promoting the usage of unleaded gasoline since 2006, the $\mathrm{Pb}$ concentration in the petroleum at Surabaya (the capital of East Java province) is still high at around 0.6-3.0 ppm (Wailanduw 2008). Meanwhile, a survey conducted during October 2011-April 2012 showed that the Pb concentration at the station away from the mud volcano and nearest to the road traffic, namely A3 ((S3=22.71; S4=2.62; S5=17.99) $\left.\mu \mathrm{g} / \mathrm{m}^{3}\right)$, was significantly higher than that at the station nearest to the mud volcano namely, A1 ((S3=21.08; S4= $\left.6.69 ; \mathrm{S} 5=5.64) \mu \mathrm{g} / \mathrm{m}^{3}\right)$. As reported by UNDAC (2006), this situation indicated that emission from motorized vehicles are the main contributor to the higher ambient $\mathrm{Pb}$ content rather than that from the mud volcano.

$\mathrm{Cr}$ and $\mathrm{Cd}$ in ambient air were detected during the survey periods S3-S5, but did not show any spatial or temporal significant differences. $\mathrm{Cr}$ concentration was as follows: A1 ((S3=0.54); $\left.(\mathrm{S} 4=9.46) ;(\mathrm{S} 5=0.16) \mu \mathrm{g} / \mathrm{m}^{3}\right) ; \mathrm{A} 2$ ((S3=0:23); (S4 = 12.83); (S5=0.20) $\left.\mu \mathrm{g} / \mathrm{m}^{3}\right)$; and A3 ((S3 $\left.=0.31) ;(\mathrm{S} 4=7: 56) ;(\mathrm{S} 5=0.14) \mu \mathrm{g} / \mathrm{m}^{3}\right) . \mathrm{Cr}$ concentration was at a safe level with reference to the OSHA permissible limit of $500 \mu \mathrm{g} / \mathrm{m}^{3}$ for Cr III (ATSDR 2008). With reference to the EPA Victoria (2003) and Uruioc (2011) the possible sources of $\mathrm{Cr}$ concentration in the ambient air of the sampling stations could have come primarily from the cement that was used for the embankment construction as well as from volcanic gas and dust. For comparison purposes, Uruioc (2011) found that the Cr content of a sample of water from the mud volcanoes in Romania was in the range of $0.02-0.05 \mathrm{ppm}$ or $42-105 \mu \mathrm{g} / \mathrm{m}^{3}$.

There was no significant $(p>0.05)$ spatial difference for $\mathrm{Cd}$ concentration among the three sampling stations i.e. A1 $\left((\mathrm{S} 3=0.86) ;\left((\mathrm{S} 4=4.15) ;\left((\mathrm{S} 5=1.13) \mu \mathrm{g} / \mathrm{m}^{3}\right) ; \mathrm{A} 2((\mathrm{~S} 3=\right.\right.$ $0.95) ;\left((\mathrm{S} 4=4.16) ;\left((\mathrm{S} 5=1.13) \mu \mathrm{g} / \mathrm{m}^{3}\right)\right.$ or $\mathrm{A} 3((\mathrm{~S} 3=0.78)$; ((S4 = 3.89); ((S5 = 1.03) $\mu \mathrm{g} / \mathrm{m}^{3}$. The low concentration of $\mathrm{Cd}$ was possibly from the naturally occurring resource of the volcanic emissions and plants (Williams \& Harrison 


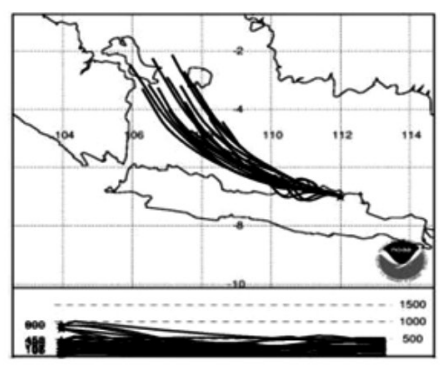

a. Survey 1 (January 2011)

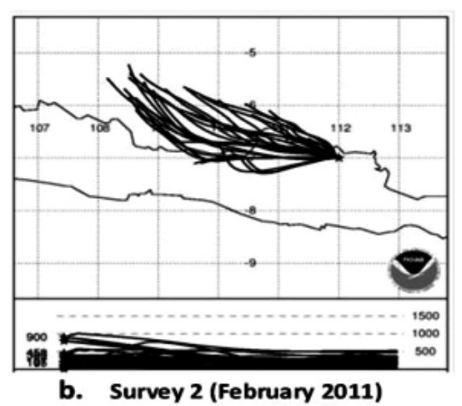

b. Survey 2 (February 2011)

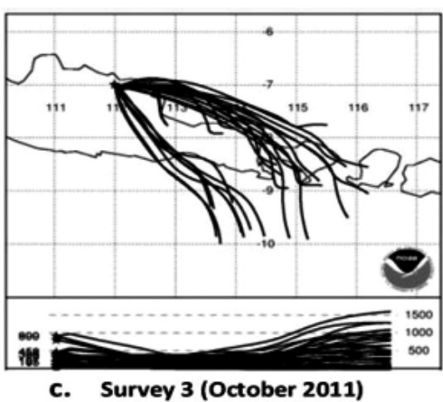

c. Survey 3 (October 2011)

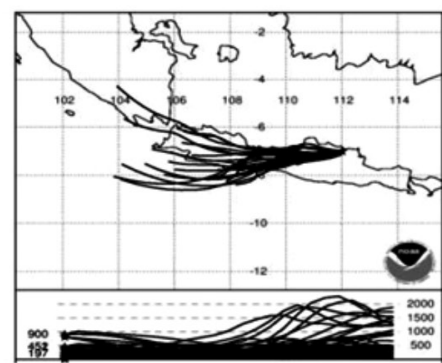

d. Survey 4 (March 2012)

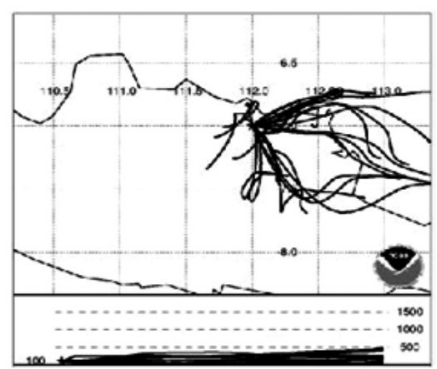

e. Survey 5 (April 2012)

FIGURE 3. Backward trajectory generated by NOAA HYSPLIT, Meteorological Data from January 2011-April 2012

1984) and largely from anthropogenic activity of the metal processing industry (Kono 2003) as well as the burning of waste materials around human settlements and agricultural areas. Overall, the average $\mathrm{Cd}$ concentration was at a safe level with reference to the OSHA limit of $5 \mu \mathrm{g} / \mathrm{m}^{3}$ (https:// www.osha.gov/dsg/topics/pel/). The similarity of $\mathrm{Cr}$ and $\mathrm{Cd}$ concentration at the sampling stations indicated that the contribution from the LUSI mud volcano with relation to the levels of $\mathrm{Cr}$ and $\mathrm{Cd}$ concentration was low and their presence was mainly from various other sources including agriculture, construction and housing activities.

Generally $\mathrm{H}_{2} \mathrm{~S}$ concentration was significantly higher at the stations that were near to the LUSI, emissions, namely A1 (2.48-2.92 ppm) and A2 (2.28-2.53 ppm) than that at the farther away station $\mathrm{A} 3(\mathrm{~S} 1=1.53-2.30)$. This indicated the possible contribution of the mud volcano emission to the $\mathrm{H}_{2} \mathrm{~S}$ content. Mazzini et al. (2007) and Plumlee et al. (2008) reported that the environment at the LUSI mud volcano crater smelled of rotten eggs, indicating the presence of $\mathrm{H}_{2} \mathrm{~S}$ (at the level of $35 \mathrm{ppm}$ ). $\mathrm{H}_{2} \mathrm{~S}$ is found naturally in crude petroleum, natural gas, volcanic gases and hot springs. The LUSI mud volcano occurred as a result of a failed project of oil drilling and natural gas exploration work (ATSDR 2006; Stamatakis et al. 1987). From previous studies, the high concentration of $\mathrm{H}_{2} \mathrm{~S}$ at the sampling stations was possibly contributed by various sources including the LUSI mud volcano, natural gas and petroleum deposits as well as from industries (ATSDR 2006; UNDAC 2006). All observed levels of $\mathrm{H}_{2} \mathrm{~S}$ concentration exceeded the stipulated levels of the East Java Governor's Regulations (Anon 2009) and the NAAQS USEPA (1990) which are 0.03 and $0.02 \mathrm{ppm}$, respectively. However, they were below the standard limit stipulated by the Occupational Safety and Health Administration (OSHA), which was 20 ppm. In comparison to the level reported by Mazzini et al. (2007), the current level of $\mathrm{H}_{2} \mathrm{~S}$ concentration shows that its level has decreased.

Geological processes can lead to high pore fluid pressure and this could result in the ejection of mud, liquids and gases such as hydrocarbons onto the surface of the earth (Niemann \& Boetius 2010). From investigations by a geological agency, it was reported that the gas emitted from LUSI consisted of hydrocarbon (HC) gases and smelled of crude oil (Zaenuddin et al. 2010) including benzene and toluene (ATSDR 2007b, 2000; UNDAC 2006). The toluene concentration ranged from 0.33-0.92 ppm (or 1230-3430 $\mu \mathrm{g} / \mathrm{m}^{3}$ ) which is below the stipulated standard of MRLs (ATSDR 2007b) as well as that of PELs and OSHA (1 and $10 \mathrm{ppm}$ or 3728.7 and $37287 \mu \mathrm{g} / \mathrm{m}^{3}$ ). Meanwhile, the content of benzene ranged from 0.33-0.40 ppm (1043-1264 $\mu \mathrm{g} / \mathrm{m}^{3}$ ), levels above the MRLs (ATSDR 2000) standards, however, they were still at a safe level according the PELs and OSHA standards. The total HC concentration at all the stations exceeded the stipulated levels of NAAQS USEPA (1990). The total HC levels at the stations near to LUSI, namely A1 (0.82-0.89 ppm) and A2 (0.68-0.96 ppm) were significantly higher than that at station A3 (0.57-0.92 ppm) indicating that LUSI contributed to higher VOC levels. However, according to a previous study done by UNDAC (2006), the VOC levels were also contributed by several other activities that occured in the vicinity of LUSI and these included digging, pumping of the mud, road traffic emissions as well as industrial emissions (ATSDR 2007b, 2000). With reference to the correlation coefficient value, 
the contribution of toluene to the total $\mathrm{HC}$ concentration $(r=0.67)$ was found to be higher than that of benzene $(r=0.01)$.

$\mathrm{NO}_{2}$-air pollution is important not only because it is a result of anthropogenic activities, but also because it reacts in the atmosphere to form ozone and acid rain (USEPA 1999). Table 1 shows that the temporal pattern of $\mathrm{NO}_{2}$ concentrations fluctuated and all observed concentrations were below $0.1 \mathrm{ppm}$ which is considered a safe level according to NAAQS, USEPA (1990). The concentrations recorded were as follows: station A1 (0.016-0.076 ppm); A2 between (0.009-0.054 ppm) and A3 (not detected-0.066), respectively. Etiope et al. (2002) and Plumlee et al. (2008) reported that the mountain of mud contained some nitrogen gas. The presence of $\mathrm{NO}_{2}$ in the mud volcano was generally the result of the reduction of nitrates by bacteria (Berner 1971). However, the contribution of $\mathrm{NO}_{2}$ from the mud volcano emission was possibly lower than that from road traffic and industrial emissions. According to the local government reports from 2005 to 2009, the level of $\mathrm{NO}_{2}$ concentration in the atmosphere of Sidoarjo was high and ranged from 10.9-26.6 ppm in heavy traffic areas while it was 2.7-4.9 ppm at industrial areas (PPSP 2011).

The mean observed $\mathrm{SO}_{2}$ concentrations (Table 1) fluctuated and there was no significant difference among the levels at the three stations, i.e. station A1 (0.021-1.096 ppm), A2 (0.021-1.938 ppm) and A3 (0.037-1.340 ppm). The observed $\mathrm{SO}_{2}$ concentration exceeded the limit of NAAQS (1990) which stipulated a level of $0.075 \mathrm{ppm} . \mathrm{SO}_{2}$ is the dominant sulfur component in the natural gas of a volcano (Textor et al. 2003). The $\mathrm{SO}_{2}$ in the atmosphere may have come from liquid volcanic plume (Brimblecombe 1996; Oppenheimer et al. 1998), the reaction between $\mathrm{H}_{2} \mathrm{~S}$ and oxygen to form water and $\mathrm{SO}_{2}$ (Kurniawati \& Azizah 2006) and various anthropogenic activities such as electrical utilities, industrial processes, combustion in industry, vehicular transportation and other activities (Sher 1998; UNDAC 2006). The Indonesian Department of Health (2006) reported that $\mathrm{SO}_{2}$ in the LUSI area was low (0.0041-0.0060 ppm). PPSP reported that the atmospheric content of $\mathrm{SO}_{2}$ and that from the Sidoarjo traffic in 2005 (before the LUSI mud volcano erupted) was at the level of $0.38 \mathrm{ppm}$, but during the initial eruption stage of the LUSI mud volcano in 2006, it increased to $1.53 \mathrm{ppm}$. However, in 2009 the level decreased to $0.38 \mathrm{ppm}$. Moreover, $\mathrm{SO}_{2}$ in the industrial areas from 2005 to 2009 was in the range of 0.803-0.860 ppm. In addition, the number of industries in Sidoarjo during the years 2011 and 2012 were 6357 and 6548, respectively. Accordingly, the high $\mathrm{SO}_{2}$ in the study area might have originated from the mud volcano but currently is obtained mostly from vehicular traffic and industrial emissions.

The AQI (Table 1) based on $\mathrm{PM}_{25}$ was between 164 217 and on $\mathrm{SO}_{2}$ it was between 235-291 indicating that the air quality status at the sampling stations were at 'unhealthy' and 'very unhealthy' levels. Together with traffic and industrial emissions, the LUSI mud volcano contributed to the Sidoarjo air pollution and thus posed a risk to human health. As discussed earlier, the dry dust of the LUSI mud could potentially produce $\mathrm{PM}_{2.5}$ hence, the surrounding area (500 $\mathrm{m}$ radius from the mud volcano) is considered risky, with high possibility of exposure to $\mathrm{PM}_{2.5}$ and therefore, unsuitable for long term human settlement as well as for use as playgrounds or recreational parks. In addition, the toxicity of fine particles near the LUSI sampling stations could be enhanced by high concentrations of $\mathrm{VOC}$, including total hydrocarbons, benzene and toluene. Moreover, the surface of $\mathrm{PM}_{2.5}$ can adsorb various organic substances such as hydrocarbons (Lindner et al. 1983) which may increase human oxidative stress and inhibit the mobility of cells (Cai-ping et al. 2013).

Another risky pollutant near the LUSI station namely $\mathrm{H}_{2} \mathrm{~S}$, was found to be at levels above $0.2 \mathrm{ppm}$ and this can be inhaled by humans (Collins \& Lewis 2000). $\mathrm{H}_{2} \mathrm{~S}$ can increase blood lactate content of muscular tissues, resulting in muscle fatigue during exercise (Bhambani \& Singh 1991).

By clustering the observed parameters (Figure 4), it was observed that $\mathrm{H}_{2} \mathrm{~S}$, VOC and $\mathrm{SO}_{2}$ exhibited a close relationship, which indicated similarities in the pattern of their pollutant levels and sources which included the LUSI mud, gas and oil deposits in the vicinity as well as the emissions from gasoline fuelled vehicles. However, $\mathrm{Cr}$, $\mathrm{Cd}, \mathrm{Pb}$ and $\mathrm{NO}_{2}$ formed a different group. As previously discussed, the $\mathrm{Cr}, \mathrm{Cd}, \mathrm{Pb}$ and $\mathrm{NO}_{2}$ are believed to arise from industrial activities and settlements rather than from the LUSI mud volcano. Next, the hierarchial position of

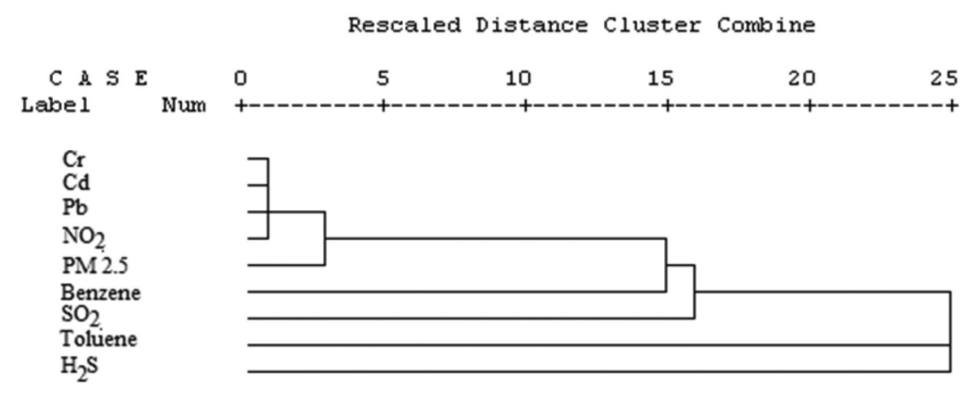

FIGURE 4. Dendrogram of hierarchical air pollutant clusters in the LUSI area 
$\mathrm{Pb}$ and $\mathrm{NO}_{2}$ are also related to $\mathrm{PM}_{2.5}$ which possibly is also related to the same pollutant source namely vehicular transportation activities.

Besides automobile activities, the hierarchial $\mathrm{PM}_{2.5}$ appears to be separate from other groups that may have arisen by the presence of other pollutants i.e. 'dust' including the dry LUSI mud, as well as road and construction dust. Constructive suggestions have been proposed which include relocating the settlements to at least $4 \mathrm{~km}$ away from the LUSI area and halting the construction of permanent buildings such as hospitals, schools and other administrative buildings. Developing and creating green lung areas within the LUSI area can also help to reduce air pollution in the neighbourhood.

\section{CONCLUSION}

The LUSI mud volcanic emission and microparticles of dried LUSI mud in Sidoarjo, Indonesia has contributed to increase in air pollution levels in the affected area especially by $\mathrm{H}_{2} \mathrm{~S}, \mathrm{SO}_{2}$ and $\mathrm{PM}_{2,5}$, respectively The AQI of $\mathrm{PM}_{2.5}$ was at levels of 164 to 217 and $\mathrm{SO}_{2}$ at 235 to 291 indicating that the air quality at the LUSI area is 'very unhealthy'.

\section{ACKNOWLEDGEMENTS}

This study was supported by research grant no. ST-2017013 from Universiti Kebangsaan Malaysia. The authors acknowledge the 'Dirjen Pendidikan Tinggi' from National Education Ministry (Indonesia) for the doctoral program scholarship while physical, chemical and biological analyses were conducted at Institut Teknologi Sepuluh Nopember Surabaya (ITS) Indonesia.

\section{REFERENCES}

ADB. 2006. Country Synthesis Report on Urban Quality Management: Indonesia. Philippines: The Asian Development Bank (ADB).

Anon. 2009. East Java Governor Regulation no. 10, Year 2009 for ambient air quality and stationary sources emissions in East Java Indonesia (Peraturan Gubernur Jawa Timur no. 10 tahun 2009 tentang baku mutu udara ambien dan emisi sumber tidak bergerak di Jawa Timur Indonesia).

Akesson, M. 2008. Mud volcano: A review. Master thesis, Lund University, Sweden (Unpublished).

ATSDR. 2008. Chromium Toxicity What Are the Standards and Regulations for Chromium Exposure? Agency for Toxic Substances and Disease Registry Atlanta, GA.

ATSDR. 2007a. Toxicological Profile for Lead. U.S. Agency for Toxic Substances and Disease Registry, U.S. Public Health Services, Department of Health and Human Services, Atlanta, GA.

ATSDR. 2007b. Toxicological Profile for Benzene. U.S. Agency for Toxic Substances and Disease Registry, U.S. Public Health Services, Department of Health and Human Services, Atlanta, GA.

ATSDR. 2006. Toxicological Profile for Hydrogen Sulfide. Agency for Toxic Substances and Disease Registry, U.S.
Public Health Services, Department of Health and Human Services, Atlanta, GA.

ATSDR. 2000. Toxicological Profile for Toluene. Agency for Toxic Substances and Disease Registry, U.S. Public Health Services, Department of Health and Human Services, Atlanta, GA.

Bhambani, Y. \& Singh, M. 1991. Physiological effects of hydrogen sulfide inhalation during exercise in healthy men. Journal of Applied Physiology 71(5): 1872-1877.

Berner, R.A. 1971. Principles of Chemical Sedimentology. New York: Mc Graw Hill

Brimblecombe, P. 1996. Air Composition and Chemistry. Cambridge: Cambridge University Press.

Brown, K.M. 1990. The nature and hydrogeological significance of mud diapirs and diatremes for accretionary prisms. Journal of Geophysical Research 95: 8969-8982.

Li, C.P., Qin, G., Shi, R.Z., Zhang, M.S. \& Lv, J.Y. 2013. Ginsenoside $\mathrm{Rg} 1$ reduces toxicity of $\mathrm{PM}_{2.5}$ on human umbilical vein endothelial cells by upregulating intracellular antioxidative state. Environmental Toxicology and Pharmacology 35(1): 21-29.

Collins, J. \& Lewis, D. 2000. Air Toxicology and Hydrogen Sulfide: Evaluation of Current California Air Quality Standards with Respect to Protection of California. Office of Environmental Health Hazard Assessment Children Epidemiology Section, California.

Creed, J.T., Martin, T.D. \& O'Dell, J.W. 1994. USEPA Method 200.9, Revision 2.2 Determination of trace elements by stabilized temperature graphite furnace atomic absorption.

Centre for Remote Imaging, Sensing and Processing (CRISP). 2012. National University of Singapore. http://www.crisps. nus.edu.sg/coverages/EJmudflow. Accessed on April 5, 2014.

Centre for Remote Imaging, Sensing and Processing (CRISP). 2011. National University of Singapore. http://www.crisps. nus.edu.sg/coverages/EJmudflow/index20110809.html. Accessed on April 5, 2014.

Centre for Remote Imaging, Sensing and Processing (CRISP). 2010. National University of Singapore. http://www.crisp. nus.edu.sg/coverages/EJmudflow/index 20101117. html. Accessed on December 7, 2010.

Davies, R.J., Mathias, S.A., Swarbick, R.E. \& Tingay, M.J. 2011. Probabilistic longevity estimate for the LUSI mud volcano, East Java. Journal of the Geological Society 168: 517-523.

Draxler, R.R. \& Rolph, G.D. 2013. Hybrid single-particle lagrangian integrated trajectory (HYSPLIT) model. http:// ready.arl.noaa.gov/HYSPLIT.php. Accesed on June 5, 2013.

EPA Victoria. 2003. Rapid Bioassessment Methodology for Rivers and Streams. Guideline for Environmental Management. Australia: EPA Victoria. pp. 1-11.

Etiope, G., Caracausi, A., Favara, R., Italiano, F. \& Baciu, C. 2002. Methane emission from the mud volcanoes of Sicily (Italy). Geophysical Research Letters 29(8): 1215.

Gokhale, S. 2009. Air Pollution Sampling and Analysis. Department of Civil Engineering, Indian Institute of Guwahati, Assam India.

Hasan, M.I. 2003. Kajian Korelasi Curah Hujan, Debit Sungai Brantas dan Anomali SML Nino 3,4 untuk Estimasi Ketersediaan Air Permukaan DAS Brantas Jawa Timur (Correlation of Rainfall, Discharge Brantas River and Anomalies SMLNino 3.4 to Estimate the Brantas River Basin Surface Water Availability in East Java). Skripsi. Department Geophysics and Meteorology, Institut Teknologi Pertanian Bogor, Indonesia. 
Hawkins, T.W. \& Holland, L.A. 2010. Synoptic and local weather condotions associated with $\mathrm{PM}_{25}$ concentration in Carlisle, Pennsylvania. Middle States Geographer 43: 72-84.

Hidayati, D., Sulaiman, N., Ismail, B.S., Shuhaimi Othman, M. \& De Bellard, M.E. 2017. Evaluation of the effect of Sidoarjo mud on aquatic life using chromatophores and the microstructure of fish scales. Sains Malaysiana 46(3): 373-380.

Hidayati, D., Sulaiman, N., Ismail, B .S. \& Shuhaimi-Othman, M. 2014. Impact of mud volcano lava to the aquatic life using the fish biological study case in lusi mud volcano Indonesia. Research Journal of Environmental Toxicology 8: 1-24.

Hidayati, D., Sulaiman, N., Ismail, B.S. \& ShuhaimiOthman, M. 2013. Fish scale deformation analysis using scanning electron microscope: New potential biomarker in aquatic environmental monitoring of aluminum and iron contamination. AIP Conference Proceedings. 1571: 563-568. https://doi.org/10.1063/1.4858714.

Hosiokangas, J., Vallius, M., Ruuskanen, J., Mirme, A. \& Pekkanen, J. 2004. Resuspended dust episodes as an urban air-quality problem in subarctic regions. Scandinavian Journal of Work, Environment \& Health 2: 28-35.

Kono, N. 2003. Urban Environmental Management Capacity Assessment: Case Study of Jakarta and Surabaya. www.iges. or.jp/kitakyushu/ Successful\%20Practices/Indicators4.pdf. Accesed on June 27, 2015.

Kurniawati, N.E. \& Azizah, R. 2006. Pengaruh penggunaan cerobong asap model "water spons filter" (WSF) terhadap penurunan kadar $\mathrm{SO}_{2}$ pada industri tahu di Sukun Malang. Jurnal Lingkungan 3(1): 59-66.

Lindner, W., Posch, W., Wolfbeis, O.S. \& Tritthart. 1983. Analysis of nitro-PAHs in diesel exhaust particulate extracts with multicolumn HPLC. Chromatographia 20(4): 213-218.

Lodhi, A., Ghauri, B., Rafiq Khan, M., Rahman, S. \& Shafique, S. 2009. Particulate matter $\left(\mathrm{PM}_{2.5}\right)$ concentration and source apportionment in Lahore. Journal of the Brazilian Chemical Society 20(10): 1811-1820.

Mazzini, A., Svensen, H., Akhmanov, G.G., Aloisi, G., Planke, S., Malthe Sorrensen, A. \& Istadi, B. 2007. Triggering and dynamic evolution of the lusi mud volcano Indonesia. Earth and Planetary Science Letters 261(3-4): 375-388.

Milkov,A.V. 2005. Global distribution of mud volcanoes and their significance in petroleum exploration as a source of methane in the atmosphere and hydrosphere and as geohazard. Nato Science Series 51: 29-34.

NAAQS USEPA. 1990. National Ambient Air Quality Standards (NAAQS). Clean Air Act. United States Environmental Protection Agency. http://epa.gov/air/criteria.html. Accessed on October, 2011.

Niemann, H. \& Boetius, A. 2010. Mud volcanoes. In Handbook of Hydrocarbon and Lipid Microbiology, edited by Timmis, K.N. Berlin Heidelberg: Springer-Verlag.

Oppenheimer, C., Francis, P. \& Stix, J. 1998. Depletion rates of sulfur dioxide in tropospheric volcanic plumes. Geophysical Research Letters 25(14): 2671-2674.

Plumlee, G.S., Casadevall, T.J., Wibowo, H.T., Rosenbauer, R.J., Johnson, C.A., Breit, G.N., Lowers, H.A., Wolf, R.E., Hageman, P.L., Goldstein, H., Anthony, M.W., Berry, C.J., Fey, D.L., Meeker, G.P. \& Morman, S.A. 2008. Preliminary Analytical Results for a Mud Sample Collected from the LUSI Mud Volcano, Sidoarjo, East Java, Indonesia. U.S. Geological Survey Open-File Report 2008.
PPSP. 2011. Program Percepatan Pembangunan Sanitasi Permukiman (Sanitation Development Acceleration Program Settlement). Buku Putih Sanitasi Kabupaten Sidoarjo. Tim Pelaksana Kelompok Kerja PPSP Kabupaten Sidoarjo (White Book Sanitation Sidoarjo. Working Group Executive Team PPSP District Sidoarjo).

Queensland EPA. 1997. Queensland Government, Environment Protection Agency. Air quality sampling manual. Produced by Department of Environment, The State of Queensland. ISBN 0724269983

Rolph, G.D. 2013. Real-time Environmental Applications and Display System (READY) Website (http://ready.arl.noaa. gov). NOAA Air Resources Laboratory, Silver Spring, MD

Sher, E. 1998. Handbook of Air Pollution from Internal Combustion Engines: Pollutant Formation and Control.Part II Global Aspect. London: Academic Press Limited.

SNI. 2005a. Standar Nasional Indonesia (National Standard of Indonesia), Emisi Gas Buang-Sumber tidak Bergerak-Bagian 5: Cara Uji Oksida-oksida Nirogen dengan Metode Phenol Disuphonic Acid (PDS) menggunakan Spectrofotometer (Exhaust Emissions - Stationary Sources - Part 5: Test Methods of Oxides Nirogen with Phenol Disuphonic Acid Method (PDS) using Spectrophotometer). No. SNI 197117.5.2005.

SNI. 2005b. Standar Nasional Indonesia (National Standard of Indonesia), Udara Ambien-Bagian 7: Cara Uji Kadar Sulfur Dioksida ( $\mathrm{SO}_{2}$ ) dengan Metoda Pararosanilin menggunakan Spektrofotometer (Ambient Air - Part 7: Test Methods for Sulfur Dioxide $\left(\mathrm{SO}_{2}\right)$ with Pararosanilin Method using a Spectrophotometer. No: SNI 19-7119.7.2005.

Stamatakis, M.G., Baltatzis, E.G. \& Skounakis, S.B. 1987. Sulfate mineral for a mud volcano in the Katakolo area western Pelloponnesus Greece. American Mineralogist 72: 839-841.

Tai,A.P.K., Mickey, L.J. \& Jacob, D.J. 2010. Correlation between fine particulate matter $\left(\mathrm{PM}_{25}\right)$ and meteorological variables in the United States: Implications for sensitivity of $\mathrm{PM}_{25}$ to climate change. Atmospheric Environment 44: 3976-3984.

Textor, C., Graf, H.F. \& Timmreck, C. 2003. Emissions from Volcanoes. In Reeves Emissions of Atmospheric Trace Compounds, edited by Granier, C.P. \& Artaxo, C.E. Dordrecht, Netherlands: Kluwer Academic Publisher.

Tiwari, S., Chate, D.M., Srivastava, A.K., Bisht, D.S. \& Padmanabhamurty, B. 2012. Assessments of $\mathrm{PM}_{1}, \mathrm{PM}_{25}$ and $\mathrm{PM}_{10}$ concentrations in Delhi at different mean cycles. Geophysics 29: 125-141.

UNDAC. 2006. United Nation Disaster Assesment and Coordination, Environmental Assessment Hot Mud Flow East Java Indonesia. Joint UNEP/OCHA Environment Unit, 1-56, Final Technical Report, July 2006, Switzerland.

Uruioc, S., Mâu, S., Sinitean, A., Albulescu, M. \& Popovici, H. 2011. Preliminary study of mud volcanoes in Banat (SouthWest Romania). Geo-Eco-Marina 17: 247-251.

USEPA. 1999. Nitrogen Oxides (NOx), Why and How They are Controlled United States Office of Air Quality EPA 456/F-99006R. Technical Bulletin Environmental Protection Planning and Standards November 1999 Agency.

USEPA. 2006. Air Quality Criteria for Lead (Final Report, 2006). U.S. Environmental Protection Agency, Washington, DC, EPA/600/R-05/144aF-bF, 2006.

Wailanduw, G. 2008. Kualiti bahan api petrol "premium": Kajian kes di Surabaya (Mutu bahan bakar premium: Studi kasus di Surabaya). Jurnal Teknika 9(2): 104-109.

Williams, C.R. \& Harrison, R.M. 1984. Cadmium in the atmosphere. Experentia 40(1): 29-36. 
Yadav, R., Sahu, L.K., Jaaffrey, S.N.A. \& Beig, G. 2014. Temporal variation of particulate matter (PM) and potential sources at an urban site of Udaipur in Western India. Aerosol and Air Quality Research 14(6): 1613-1629.

Zaenuddin, A., Badri, I., Padmawidjaja, T., Humaida, H. \& Sutaningsih, E. 2010. Fenomena geologi semburan lumpur Sidoarjo (Geological phenomenon of Sidoarjo mudflow). Badan Geologi, Kementerian Energi dan Sumber Daya Mineral (Geology Agency, Ministry of Energy and Mineral Resources).

Dewi Hidayati

Biology Department, Mathematics and Natural Science Faculty Institut Teknologi Sepuluh Nopember Surabaya (ITS)

Indonesia
Dewi Hidayati, Ismail, B.S., Shuhaimi-Othman, M. \& Norela Sulaiman*

School of Environmental and Natural Resource Sciences Faculty of Science and Technology

Universiti Kebangsaan Malaysia

43600 UKM Bangi, Selangor Darul Ehsan

Malaysia

*Corresponding author; email: vozela@ukm.edu.my

Received: 3 July 2017

Accepted: 11 March 2018 